\title{
OPTIMASI KONSENTRASI ENZIM PAPAIN DAN SUHU PEMANASAN PADA PEMBUATAN DANGKE DENGAN RESPONSE SURFACE METHOD (RSM)
}

\section{Optimization of Papain Enzyme Concentration and Heating Temperature in Making Dangke Using Response Surface Method (RSM)}

\author{
Maimunah Hindun Pulungan*, Marta Muthia Kamilia, Ika Atsari Dewi \\ Jurusan Teknologi Industri Pertanian - Fakultas Teknologi Pertanian - Universitas Brawijaya \\ Jl. Veteran - Malang 65145 \\ *Penulis Korespondensi, email: maimun2010@ub.ac.id
}

Disubmit: 1 September 2019 Direvisi: 27 Januari 2020 Diterima: 10 Februari 202

\begin{abstract}
ABSTRAK
Tujuan penelitian mengetahui konsentrasi enzim papain serta suhu pemanasan yang optimal sehingga diperoleh dangke dengan kualitas dan penerimaan konsumen yang baik. Penelitian dirancang menggunakan Response Surface Method menggunakan Rancangan Komposit Terpusat dengan dua faktor. Faktor pertama konsentrasi enzim papain $(0,1 \% ; 0,3 \% ; 0,5 \%)$ dan faktor kedua suhu pemanasan $\left(65^{\circ} \mathrm{C} ; 75^{\circ} \mathrm{C} ; 85^{\circ} \mathrm{C}\right)$. Hasil solusi optimal diperoleh pada perlakuan konsentrasi enzim papain sebesar $0,21 \%$ dan suhu pemanasan sebesar $77,73{ }^{\circ} \mathrm{C}$ dengan dangke yang memiliki nilai kadar protein sebesar $11,93 \%$, total padatan terlarut whey dangke sebesar $6,31^{\circ} \mathrm{Brix}$ dan rendemen sebesar $14,44 \%$. Warna netral, tekstur agak tidak menyukai, rasa tidak menyukai dan aroma netral.
\end{abstract}

Kata Kunci: Dangke; Enzim Papain; Response Surface Method; Suhu Pemanasan

\begin{abstract}
The purpose is to determine the concentration of the papain enzyme and heating temperature the optimal in order to obtained with quality and good consumer acceptance. The study was designed used the Response Surface Method with Centralized Composite Design with two factors. The first factor is the concentration of the papain enzyme $(0.1 \% ; 0.3 \% ; 0.5 \%)$ and the second factor is the heating temperature $\left(65^{\circ} \mathrm{C} ; 75^{\circ} \mathrm{C} ; 85^{\circ} \mathrm{C}\right)$. The optimal solution results obtained in the treatment of papain enzyme concentration of $0.21 \%$ and heating temperature of $77.73{ }^{\circ} \mathrm{C}$ with dangke which has a protein content value of $11.93 \%$, the total dissolved solids of whey dangke amounted to $6.31^{\circ}$ Brix and the yield of $14.44 \%$. Neutral color, somewhat disliked texture, disliked taste and neutral aroma.
\end{abstract}

Keywords: Dangke; Heating Temperature; Papain Enzyme; Response Surface Method

\section{PENDAHULUAN}

Indonesia memiliki produk olahan susu tradisional, salah satunya adalah dangke. Dangke merupakan produk yang menyerupai keju lunak segar dari Kabupaten Enrekang Sulawesi Selatan (Hatta et al., 2013). Baarri et al. (2018) menyatakan, produksi dangke meningkat seiring dengan peningkatan permintaan konsumen. Distribusi dangke telah menjangkau pulau Jawa dan Sumatra bahkan negara Brunei Darussalam dan Malaysia, namun usaha dangke masih berupa industri rumah tangga dengan menggunakan 
teknologi yang sederhana (Rahman, 2014). Proses produksi teknologi yang sederhana ini akan berpengaruh pada kualitas dangke yang dihasilkan.

Dangke dibuat dengan memanaskan susu segar lalu diaduk agar partikel susu mem-peroleh panas secara merata. Kemudian getah pepaya ditambahkan pada susu yang sebe-lumnya dilarutkan dengan air terlebih dahulu dan kembali diaduk agar getah larut sehingga dapat menggumpalkan protein susu. Gumpalan susu (curd) disaring untuk dipisahkan dari cairan (whey) sekaligus dicetak menggunakan tempurung kelapa. Curd dicetak dalam kondisi panas dengan ditekantekan agar tekstur menjadi lebih kompak. Kemudian dangke dikemas menggunakan daun pisang. Kualitas dangke yang diperoleh ha-nya didasarkan pada tekstur serta rasa yang dihasilkan. Getah pepaya yang dilarutkan dengan air terlebih dahulu sebelum digunakan tidak diketahui perbandingan dan konsentrasi getah yang digunakan (Hatta et al., 2014). Penggunaan koagulan getah pepaya dirasa kurang efektif untuk perkembangan dangke dikarenakan setiap pembuatan dangke harus menyadap getah pepaya dahulu agar getah masih segar karena getah mempunyai daya simpan yang tidak bertahan lama (Suyanti et al., 2012). Alternatif pengganti koagulan getah pepaya yaitu enzim papain sehingga daya simpannya lebih lama dan bisa digunakan beberapa kali.

Enzim papain diperoleh dari pemurnian getah tanaman pepaya yang dimanfaatkan untuk industri minuman, makanan, pengolahan daging, pengolahan ikan, farmasi, kosmetik serta tekstil (Warisno, 2003). Penelitian mengenai penggunaan enzim papain sebagai koagulan telah dilakukan oleh Arlene et al. (2014) yaitu dalam pembuatan keju dengan koagulan berupa enzim papain diperoleh rendemen $10,75 \%$; kadar protein $0,62 \%$; kadar air 42,5\%; kadar lemak 0,077\%; dan kadar abu $0,046 \%$. Berdasarkan hal tersebut, enzim papain dapat digunakan sebagai koagulan pengganti getah pepaya pada pembuatan dangke.

Kualitas dangke yang baik dengan adanya kandungan gizi menjadi aspek yang dipertimbangkan oleh konsumen. Mukhlisah et al. (2017) menyatakan bahwa penambahan konsentrasi enzim papain dan suhu pemanasan berpengaruh pada kualitas dangke. Jika konsentrasi enzim papain yang digunakan terlalu tinggi akan menurunkan nilai ren- demen, sedangkan suhu pemanasan yang terlalu tinggi berpengaruh pada rendah-nya kadar protein dan kadar air pada dangke. Optimasi konsentrasi enzim papain dan suhu pemanasan diharapkan mampu memperbaiki kualitas dangke, sehingga tujuan penelitian untuk mengetahui konsentrasi enzim papain serta suhu pemanasan yang optimal sehingga diperoleh dangke dengan kualitas dan penerimaan konsumen yang baik.

\section{METODE}

Pembuatan dangke menggunakan alat timbangan digital (Mettler), panci, kompor (Rinnai), sendok, termometer digital TP-101, saringan plastik 40 mesh, kain saring 80 mesh, dan cetakan dari aluminium foil. Alat untuk analisa meng-gunakan timbangan (Mettler), oven (Mem-mert), tanur (Thermolyne), soxhlet extractor, kjeldahl des-tilation unit (Buchi), desikator, labu lemak, buret, statif, cawan aluminium, cawan por-selen, mortar, kertas saring, spatula, dan refraktometer.

Bahan yang digunakan untuk pembuatan dangke adalah enzim papain impor yang diproduksi oleh Perusahaan Nanning Pangbo Biological Engineering dari China, susu sapi segar dari KUD Batu Malang, dan garam dapur merek "Kapal". Bahan yang digunakan untuk analisa adalah sampel dangke, $\mathrm{H}_{2} \mathrm{SO}_{4}$, $\mathrm{NaOH}, \mathrm{H}_{3} \mathrm{BO}_{3}, \mathrm{HCl}$, in-dikator metil biru, indikator metil merah, tablet kjeldahl (mengandung $\mathrm{K}_{2} \mathrm{SO}_{4}$ dan $\mathrm{CuSO}_{4}$ ), dan aquades.

\section{Rancangan Penelitian}

Penelitian menggunakan Response Surface Method (RSM) dengan Rancangan Komposit Terpusat (Central Composit Design) dengan 2 faktor yaitu konsentrasi enzim papain $\left(X_{1}\right)$ dan suhu pemanasan $\left(X_{2}\right)$, masing-masing faktor mempunyai tiga level dengan kode $+1,-1$, dan 0 . Faktor konsentrasi enzim papain mempunyai titik bawah $0,1 \%$ $\left(X_{1}=-1\right)$, titik tengah $0,3 \% \quad\left(X_{1}=0\right)$, serta titik atas $0,5 \%\left(X_{1}=+1\right)$. Faktor suhu pemanasan mempunyai titik bawah $65^{\circ} \mathrm{C}\left(\mathrm{X}_{2}=-1\right)$, titik tengah $75^{\circ} \mathrm{C}\left(\mathrm{X}_{2}=0\right)$, dan titik atas $85^{\circ} \mathrm{C}$ $\left(\mathrm{X}_{2}=+1\right)$. Respon yang dioptimasi yaitu kadar protein dangke, total padatan terlarut whey dangke, kadar air dangke dan rendemen dangke. 


\section{Pelaksanaan Penelitian}

Air $2000 \mathrm{ml}$ dimasukkan dalam wadah panci dengan diameter $20 \mathrm{~cm}$, kemudian susu sapi segar sebanyak $1000 \mathrm{ml}$ dimasukkan dalam wadah panci dengan diameter $18 \mathrm{~cm}$. Wadah panci yang berisi susu sapi segar kemudian dimasukkan kedalam wadah panci yang berisi air. Setelah itu susu sapi segar dan air dalam wadah panci dipanaskan sampai suhu sesuai perlakuan sambil sesekali diaduk menggunakan sendok. Kemudian susu sapi ditambahkan enzim papain sesuai perlakuan dan ditambahkan garam $1 \%$. Setelah itu diaduk menggunakan sendok sampai terbentuk gumpalan (curd), gumpalan (curd) kemudian disaring dari whey menggunakan kain saring dan saringan plastik. Kemudian gumpalan (curd) ditekan-tekan dengan sendok hingga memadat untuk membantu memi-sahkan whey yang masih terdapat pada curd.

\section{Metode Analisis}

Analisis yang dilakukan yaitu analisis kadar protein metode kjeldhal (AOAC, 2005), analisis total padatan terlarut whey (SNI 013546-2004), analisis kadar air menggunakan moisture analyzer (Nollet dan Fidel, 2008), analisis rendemen (Nugroho et al., 2018), analisis kadar lemak metode ekstraksi soxhlet (AOAC, 2005), analisis kadar abu metode gravimetri (AOAC, 2005), dan analisis organoleptik metode hedonic scale scoring (Lawless dan Hildegarde, 2010).

\section{Analisis Data}

Data yang telah didapatkan dari pengujian kadar protein dangke, total padatan terlarut whey dangke, kadar air dangke, dan rendemen dangke kemudian diolah menggunakan program Design Expert 7.5.

\section{HASIL DAN PEMBAHASAN}

\section{Kadar Protein Dangke}

Analisa pemilihan model berdasarkan model urutan jumlah kuadrat yang disarankan adalah model kuadratik yang mempunyai nilai $F$ sebesar 1,75 dengan $p$ sebesar 0,2427 . Nilai $p>0,05$ maka model kuadratik memiliki pengaruh yang tidak signifikan terhadap respon kadar protein. Berdasarkan uji ketidaktepatan model, nilai $\mathrm{p}$ untuk model kuadratik sebesar 0,2741 ( $p>0,05)$, hal ini menunjukkan model kuadratik merupakan model yang sesuai untuk respon kadar protein sebesar $27,41 \%$. Berdasarkan ringkasan model statistik, diperoleh nilai $R^{2}$ sebesar 0,5418 yang be-rarti faktor mampu mempengaruhi respon sebesar $54,18 \%$. Rerata kadar protein pada berbagai konsentrasi enzim papain dan suhu pemanasan disajikan dalam Tabel 1.

Hasil analysis of variance (ANOVA) menunjukkan pengaruh faktor konsentrasi enzim papain dan suhu pemanasan ter-hadap respon kadar protein tidak ber-pengaruh signifikan karena mempunyai nilai $\mathrm{p}$ masingmasing 0,089 ( $p>0,05)$ dan 0,496 ( $p>0,05)$. Kemudian hubungan antar faktor terhadap respon kadar protein dija-barkan pada persamaan aktual yang ditu-njukkan pada persamaan (1), selain itu juga digambarkan dalam bentuk response surface tiga dimensi yang ditunjukkan pada Gambar 1.

$Y=-42,31+36,54 X_{1}+1,37 X_{2}-0,32 X_{1} X_{2}-$ $32,71 \mathrm{X}_{1}^{2}-8,88 \mathrm{E}-003 \mathrm{X}_{2}^{2}$.

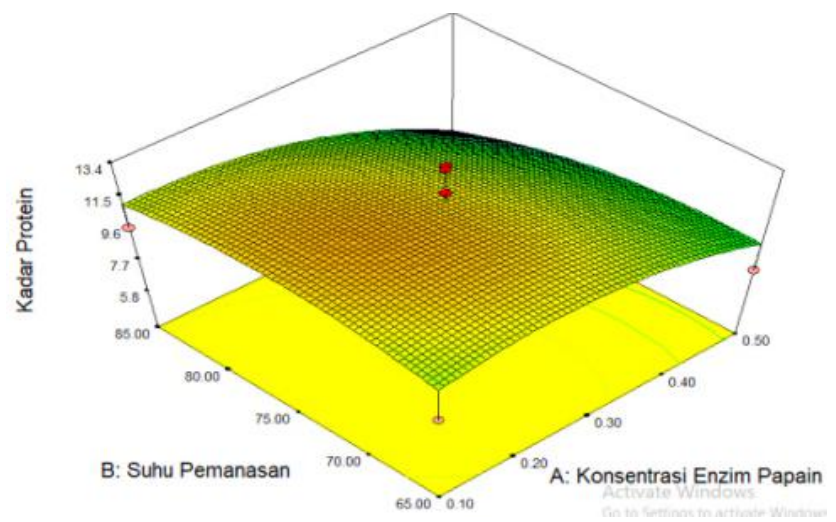

Gambar 1. Response surface tiga dimensi kadar protein dangke 
Tabel 1. Rerata respon pada berbagai konsentrasi enzim papain dan suhu pemanasan

\begin{tabular}{|c|c|c|c|c|c|c|c|c|}
\hline \multicolumn{3}{|c|}{ Variabel Kode } & \multicolumn{3}{|c|}{ Variabel Asli } & \multicolumn{3}{|c|}{ Respon } \\
\hline o & X1 & $\mathrm{X} 2$ & $\begin{array}{l}\text { Konsentrasi } \\
\text { Enzim } \\
\text { Papain (\%) }\end{array}$ & $\begin{array}{c}\text { Suhu } \\
\text { Pemanasan } \\
\left({ }^{\circ} \mathrm{C}\right)\end{array}$ & $\begin{array}{c}\text { Kadar } \\
\text { Protein } \\
(\%)\end{array}$ & $\begin{array}{c}\text { Total } \\
\text { Padatan } \\
\text { Terlarut } \\
\text { Whey } \\
\text { ('Brix) }\end{array}$ & $\begin{array}{l}\text { Kadar } \\
\text { Air } \\
(\%)\end{array}$ & $\begin{array}{l}\text { Rendemen } \\
(\%)\end{array}$ \\
\hline & -1 & -1 & 0,1 & 65 & 8,89 & 6,8 & 53,40 & 13,06 \\
\hline & 1 & -1 & 0,5 & 65 & 7,56 & 7,4 & 56,13 & 11,79 \\
\hline & -1 & 1 & 0,1 & 85 & 9,74 & 6,7 & 54,47 & 14,65 \\
\hline & 1 & 1 & 0,5 & 85 & 5,82 & 6,6 & 59,16 & 13,45 \\
\hline & $-1,414$ & 0 & 0,02 & 75 & 12,83 & 6,6 & 52,35 & 13,84 \\
\hline & 1,414 & 0 & 0,58 & 75 & 8,21 & 7,0 & 59,31 & 12,55 \\
\hline & 0 & $-1,414$ & 0,3 & 60,86 & 12,56 & 7,2 & 51,05 & 12,27 \\
\hline & 0 & 1,414 & 0,3 & 89,14 & 10,16 & 6,5 & 57,59 & 14,09 \\
\hline & 0 & 0 & 0,3 & 75 & 10,68 & 6,5 & 59,09 & 14,12 \\
\hline 0 & 0 & 0 & 0,3 & 75 & 13,40 & 5,8 & 53,60 & 14,34 \\
\hline 1 & 0 & 0 & 0,3 & 75 & 13,20 & 6,4 & 53,04 & 14,43 \\
\hline 2 & 0 & 0 & 0,3 & 75 & 11,59 & 6,4 & 52,88 & 14,26 \\
\hline 3 & 0 & 0 & 0,3 & 75 & 9,11 & 6,6 & 56,96 & 13,47 \\
\hline
\end{tabular}

Gambar 1. menunjukkan tingginya konsen-trasi enzim papain akan menurunkan kadar protein. Hal tersebut diduga konsentrasi enzim papain yang tinggi menyebabkan pembentukan curd dangke menjadi kurang sempurna. Menurut Khattak et al. (2006), enzim melakukan katalisis pada satu substrat sehingga ketika substrat yang tersedia terbatas namun enzim yang digunakan berlebihan menyebabkan aktivitas enzim terhenti ketika substrat telah habis. Pardede et al. (2013) menambahkan, konsentrasi enzim yang terlalu tinggi mengakibatkan aktivitas enzim menjadi tidak optimal, hal ini berpengaruh pada curd yang diperoleh menjadi lebih rendah dan akan mempengaruhi kandungan protein pada curd yang dihasilkan.

Suhu pemanasan yang sesuai mampu meningkatkan kadar protein pada dangke. Hal ini diduga dikarenakan enzim akan bekerja dalam kondisi terbaik dibantu dengan adanya suhu pemanasan enzim papain yang optimum sehingga pembentukan curd dangke terjadi secara maksimal dan meningkatkan kadar protein pada dangke. Enzim papain memiliki suhu optimum sebesar $65-70^{\circ} \mathrm{C}$ (Walsh, 2002) Menurut Mukhlisah et al. (2017) pada penelitiannya menyatakan bahwa terdapat penurunan terhadap kadar protein dangke yang cukup signifikan jika suhu pema-nasan ditingkatkan hingga mencapai $90^{\circ} \mathrm{C}$. Hal ini diduga karena enzim memiliki batasan suhu tertentu yang menyebabkan enzim menjadi terdenaturasi dan tidak berfungsi, sedangkan suhu pemanasan yang terlalu rendah menyebabkan kerja en-zim terhambat sehingga penggumpalan menjadi kurang optimal yang mengaki-batkan terdapat protein yang tidak meng-gumpal dan menyebabkan kadar protein menjadi rendah (Saini, 2010).

\section{Total Padatan Terlarut Whey Dangke}

Analisa pemilihan model berdasarkan model urutan jumlah kuadrat yang disarankan adalah model kuadratik dengan ni-lai F 7,05 serta nilai p 0,0210. Nilai $p<0,05$ maka model kuadratik memiliki pengaruh signifikan terhadap respon.

Berdasarkan uji ketidaktepatan model, nilai p model kuadratik sebesar $0,9948(p>0,05)$ yang menunjukkan model kuad-ratik merupakan model yang sesuai sebesar 99,48\%. Pada ringkasan model statistik, diperoleh nilai $R^{2}$ sebesar 0,7916 yang berarti faktor mampu mempengaruhi res-pon sebesar 
$79,16 \%$. Rerata total padatan terlarut whey pada berbagai konsentrasi enzim papain dan suhu pemanasan disajikan pada Tabel 1.

Hasil analysis of variance (ANOVA) menunjukkan faktor konsentrasi enzim papain terhadap respon total padatan terlarut whey tidak berpengaruh signifikan dengan nilai p 0,158 ( $>00,05)$, sedangkan fakor suhu pemanasan berpengaruh signifikan karena mempunyai nilai p 0,03 ( $\mathrm{p}<0,05)$. Hubungan faktor antar faktor terhadap respon total padatan terlarut whey dijabarkan dengan persamaan aktual yang ditunjukkan pada persamaan (2) serta digambarkan dalam bentuk response surface tiga dimensi yang ditunjukkan pada Gambar 2.

$Y=21,54+3,59 X_{1}-0,39 X_{2}-0,08 X_{1} X_{2}+6,06 X_{1}{ }^{2}$ $+2,68 \mathrm{E}-003 \mathrm{X}_{2}^{2}$.

Gambar 2. menunjukkan suhu pemanasan dibawah $65^{\circ} \mathrm{C}$ meningkatkan respon total padatan terlarut whey dangke. Hal ini diduga suhu pemanasan rendah menyebabkan aktivitas enzim papain terhambat sehingga penggumpalan curd menjadi tidak maksimal dan mengakibatkan masih terdapat padatan (kasein) yang belum menggumpal yang akan terlarut pada whey. Saini (2010) menyatakan, enzim papain bekerja secara maksimal pada suhu optimumnya, suhu optimum enzim papain yaitu sebesar $65-70^{\circ} \mathrm{C}$ (Walsh, 2002). Enzim papain yang bekerja pada suhu optimum menunjukkan kinerja enzim sedang dalam kondisi terbaik sehingga proses pembentukan curd menjadi maksimal dan dapat menurunkan total padatan terlarut pada whey.
Gambar 2. juga menunjukkan penambahan konsentrasi enzim papain yang terlalu tinggi dapat meningkatkan respon total padatan terlarut pada whey dangke. Menurut Nugroho et al. (2018), proses penggumpalan curd yang tidak optimal akibat dari proses pemecahan protein (kasein) secara berlebihan yang disebabkan tingginya konsentrasi enzim yang dig-unakan sehingga kasein banyak yang ter-larut dalam air whey. Sulmiyati dan Rah-mawati (2017) menambahkan, tingginya penambahan kadar enzim papain tidak hanya menyebabkan terlarutnya protein (kasein) pada whey, tetapi juga terdapat laktosa yang berikatan dengan molekul protein sehingga laktosa juga ikut terlarut pada whey. Hal tersebut menyebabkan total padatan terlarut pada whey akan meningkat.

\section{Kadar Air Dangke}

Analisa pemilihan model berdasarkan model urutan jumlah kuadrat yang disarankan adalah model linier dengan nilai $\mathrm{F}$ 7,55 dan nilai $p$ 0,0100. Nilai $p<0,05$ maka model linier memiliki pengaruh signifikan terhadap respon kadar air. Berdasarkan uji ketidaktepatan model, nilai $\mathrm{p}$ untuk model sebesar 0,9650 ( $p>0,05)$ yang menunjukkan model linier meru-pakan model yang sesuai sebesar 96,50\%. Pada ringkasan model statistik diperoleh nilai $\mathrm{R}^{2}$ sebesar 0,6016 yang berarti kon-sentrasi enzim papain dan suhu pemanasan mam-pu mempengaruhi respon kadar air sebesar 60,16\%. Rerata kadar air pada berbagai konsentrasi enzim papain dan suhu pemanasan disajikan dalam Tabel 1.

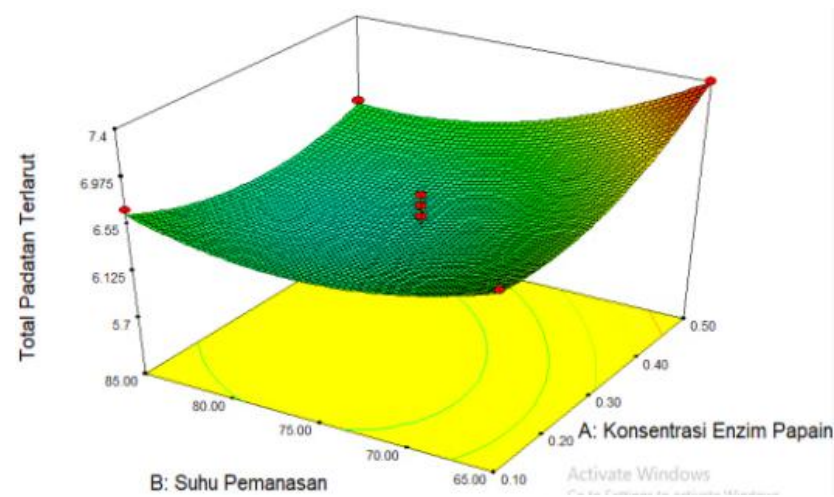

Gambar 2. Response surface tiga dimensi total padatan terlarut whey dangke 


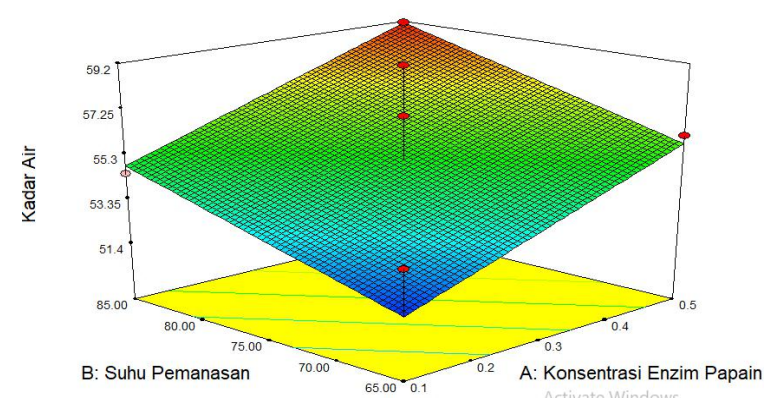

Gambar 3. Response surface tiga dimensi kadar air dangke

Hasil analysis of variance (ANOVA) menunjukkan faktor konsentrasi enzim papain memiliki nilai p 0,0100 $(\mathrm{p}<0,05)$ dan faktor suhu pemanasan memiliki nilai $p$ $0,0118(\mathrm{p}<0,05)$ yang berarti kedua faktor berpengaruh signifikan. Kemudian hubungan antar faktor terhadap respon dijabarkan dengan persamaan aktual pada persamaan (3) serta digambarkan dalam response surface tiga dimensi yang ditunjukkan pada Gambar 3.

$Y=39,56+10,79 X_{1}+0,17 X_{2}$

Gambar 3. menunjukkan bahwa respon kadar air meningkat seiring meningkatnya enzim papain dan suhu pemanasan. Hal ini diduga tingginya penggunaan konsentrasi enzim menyebabkan pembentukan curd menjadi tidak optimal sehingga dangke yang dihasilkan memilki tekstur yang berarir dan lembek. Yuniwati (2008) menyatakan dangke dengan tekstur lembek masih mengandung cukup banyak air sehingga kadar air dangke menjadi tinggi. Menurut Bansal et al. (2007), penambahan persentase enzim yang terlalu berlebihan menyebabkan kasein menjadi jenuh yaitu sehubungan dengan terbatasnya jumlah kasein yang tersedia, sehingga kasein yang terikat dengan enzim jumlahnya konstan. Hal ini membuat aktivitas enzim tidak dapat bekerja optimal dan menyebabkan terjadi penahanan air dalam curd sehingga kadar air pada curd akan meningkat.

Berdasarkan Gambar 3., meningkatnya suhu pemanasan menyebabkan kadar air yang dihasilkan juga meningkat, hal tersebut diduga dikarenakan ketika terjadi proses penekanan curd tekanan yang diberikan kurang maksimal karena penekanan dilakukan secara manual sehingga masih terdapat air whey dalam curd. Chitranayak et al. (2017) menyatakan proses penekanan curd dengan tekanan yang se-suai berpengaruh terhadap kadar air curd, hal ini menyebabkan agregat-agregat curd bergabung dan memadat sehingga air whey yang keluar dari curd menjadi lebih banyak dan air dalam curd menjadi lebih rendah.

\section{Rendemen Dangke}

Analisa pemilihan model berdasarkan model urutan jumlah kuadrat yang disarankan adalah model kuadratik yang memiliki nilai $F 12,77$ serta nilai $p$ 0,0210

Nilai $p<0,05$ maka model kuadratik berpengaruh signifikan terhadap respon. Berdasarkan uji ketidaktepatan model, nilai nilai $p$ untuk model sebesar $0,8515(p>0,05)$ yang berarti model kuadratik merupakan model yang sesuai untuk respon sebesar $85,15 \%$. Pada ringkasan model statistik, diperoleh Nilai $\mathrm{R}^{2}$ sebesar 0,9285 yang berarti faktor mampu mempengaruhi respon rendemen sebesar $92,85 \%$. Rerata rendemen pada berbagai konsentrasi enzim papain dan suhu pemanasan disajikan dalam Tabel 1.

Hasil analysis of variance (ANOVA) menunjukkan konsentrasi enzim papain memiliki nilai $p$ 0,0020 $(p<0,05)$ dan suhu pemanasan memiliki nilai $p 0,0003(p<0,05)$, ini menunjukkan kedua faktor mempunyai pengaruh yang signifikan pada respon rendemen. Kemudian hubungan antar faktor terhadap respon rendemen dijabarkan pada persamaan aktual yang ditunjukkan pada persamaan (4) serta digambarkan dalam bentuk response surface tiga dimensi yang ditunjukkan pada Gambar 4.

$\mathrm{Y}=-17,19+3,44 \mathrm{X}_{1}+0,76 \mathrm{X}_{2}+8,75 \mathrm{E}-003 \mathrm{X}_{1} \mathrm{X}_{2}-$ $11,30 \mathrm{X}_{1}^{2}-4,59 \mathrm{E}-003 \mathrm{X}_{2}^{2}$........... 
Tabel 2. Batas optimasi untuk respon penelitian

\begin{tabular}{|c|c|c|c|c|c|c|}
\hline \multirow{2}{*}{ Kriteria } & \multirow{2}{*}{ Nama (Satuan) } & \multirow{2}{*}{ Tujuan } & \multicolumn{2}{|c|}{ Batas Bawah } & \multicolumn{2}{|c|}{ Batas Atas } \\
\hline & & & Standar & Penelitian & Standar & Penelitian \\
\hline Faktor & $\begin{array}{c}\text { Konsentrasi } \\
\text { Enzim Papain (\%) }\end{array}$ & Dalam Range & 0,1 & 0,5 & 0,1 & 0,5 \\
\hline Faktor & $\begin{array}{l}\text { Suhu Pemanasan } \\
\qquad\left({ }^{0} \mathrm{C}\right)\end{array}$ & Dalam Range & 65 & 85 & 65 & 85 \\
\hline Respon & $\begin{array}{c}\text { Kadar Protein }(\%) \\
\text { Total Padatan }\end{array}$ & Maksimum & $10,29^{a}$ & 5,8 & $16,86^{\mathrm{a}}$ & 13,40 \\
\hline Respon & $\begin{array}{l}\text { Terlarut Whey } \\
\left.\text { ( }{ }^{0} \text { Brix }\right)\end{array}$ & Minimum & $6,2^{\mathrm{b}}$ & 5,8 & $7^{c}$ & 7,4 \\
\hline Respon & Rendemen (\%) & Maksimum & $11,88^{\mathrm{a}}$ & 11,79 & $15.66^{\mathrm{a}}$ & 14,65 \\
\hline
\end{tabular}

Keterangan: a) Mukhlisah et al. (2017), b) Dattatreya dan Scott (2006), ${ }^{\mathrm{c}}$ Nguyen et al. (2003)

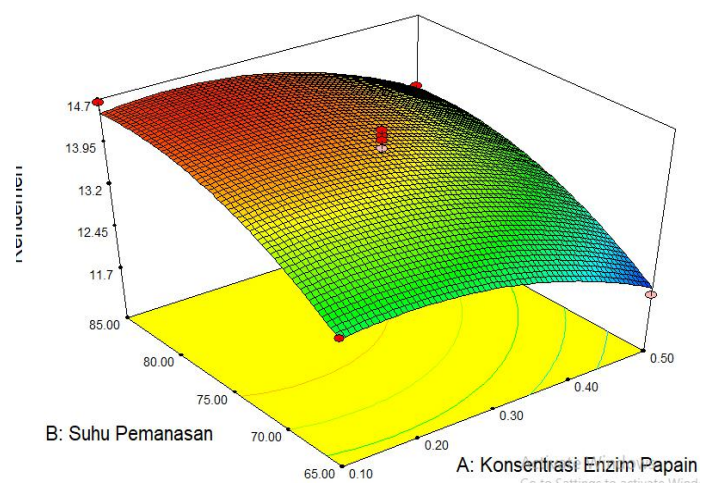

Gambar 4. Response Surface tiga dimensi rendemen dangke

Berdasarkan Gambar 4, tingginya suhu pemanasan berpengaruh pada rendemen dangke. Hal ini diduga meningkatnya suhu pemanasan berpengaruh terhadap kecepatan reaksi enzimatis. Menurut Suhandana et al. (2013), peningkatan suhu pemanasan dapat meningkatkan energi kinetik enzim dimana molekul-molekul substrat dan enzim semakin cepat gerakannya dan berpeluang besar terjadi tumbukan dan memaksi-malkan pembentukan produk. Winarti et al. (2007) menambahkan, peningkatan suhu dapat membantu reaksi enzimatis dalam menghidrolisis protein sehingga akan diha-silkan rendemen yang semakin tinggi.

Gambar 4. juga menunjukkan peningkatan konsentrasi enzim papain menyebabkan rendemen rendah. Menurut Pardede et al. (2013), penambahan konsentrasi enzim yang berlebihan menyebabkan aktivitas enzim menjadi tidak optimal karena substrat yang tersedia jumlahnya tidak memadai sehingga pembentukan curd menjadi tidak optimal. Wardhani et al. (2018) menambahkan, enzim yang bekerja optimal mampu menghasilkan rendemen lebih banyak karena terjadi peningkatan reaksi dalam memecah kasein menjadi curd sehingga curd yang dihasilkan lebih banyak, namun kinerja enzim yang tidak maksimal menyebabkan ketidakstabilan pada kasein ketika terjadi pemecahan kasein sehingga mengakibatkan kasein banyak yang terlarut dalam whey dan rendemen yang dihasilkan akan semakin rendah.

\section{Optimasi Respon}

Respon kadar protein, total padatan terlarut whey, dan rendemen mempunyai model kuadratik, sehingga disertakan dalam penentuan titik optimum. Respon kadar air memiliki model linier sehingga tidak disertakan dalam penentuan titik optimum. Optimasi dilakukan dengan batasan yang telah ditentukan yang disajikan pada Tabel 2. 
Tabel 3. Solusi hasil komputasi

\begin{tabular}{|c|c|c|c|}
\hline \multicolumn{2}{|r|}{ Parameter } & \multicolumn{2}{|c|}{ Hasil Solusi Titik Optimum } \\
\hline Konsentrasi Enzim Pap & & \multicolumn{2}{|c|}{$0,21 \%$} \\
\hline Suhu Pemanasan & & \multicolumn{2}{|c|}{$77,73^{\circ} \mathrm{C}$} \\
\hline Kadar Protein (\%) & & \multicolumn{2}{|c|}{$11,93 \%$} \\
\hline Total Padatan Terlarut & hey & \multicolumn{2}{|c|}{$6,31^{0}$ Brix } \\
\hline Rendemen & & \multicolumn{2}{|c|}{$14,44 \%$} \\
\hline Desirability & & \multicolumn{2}{|c|}{0,63} \\
\hline Parameter & Kadar Protein (\%) & $\begin{array}{c}\text { Total Padatan Terlarut } \\
\text { Whey }\left({ }^{0} \mathrm{Brix}\right)\end{array}$ & Rendemen (\%) \\
\hline Prediksi Tertinggi & 17,38 & 6,92 & 15,25 \\
\hline Prediksi Optimum & 11,93 & 6,31 & 14,44 \\
\hline Prediksi Terendah & 6,48 & 5,69 & 13,62 \\
\hline Hasil Verifikasi & 21,96 & 6,03 & 14,01 \\
\hline
\end{tabular}

Hasil dari optimasi kemudian didapatkan solusi optimal pada Tabel 3. Hasil solusi optimal diperoleh pada konsentrasi enzim papain sebesar $0,21 \%$ dan suhu pemanasan sebesar $77,73^{\circ} \mathrm{C}$, dengan desirability sebesar 0,63\%. Desirability menunjukkan kesesuaian formula respon yang diperoleh dari program dengan nilai respon yang diinginkan. Nilai desirability berkisar dari 0 hingga 1, nilai mendekati 1 berarti formula respon yang diperoleh semakin mendekati formula respon yang diinginkan (Waziiroh dan Nur, 2016).

\section{Verifikasi Kondisi Optimum Hasil Prediksi}

Data yang digunakan untuk verifikasi yaitu data hasil solusi optimum dengan konsentrasi enzim papain sebesar $0,21 \%$ serta suhu pemanasan sebesar $77,73^{\circ} \mathrm{C}$. Proses verifikasi dilakukan sebanyak tiga kali pengulangan, kemudian dilakukan perbandingan hasil verifikasi dengan hasil prediksi oleh program pada Tabel 4. Hasil verifikasi untuk kadar protein lebih tinggi dari rentang prediksi yaitu sebesar $21,96 \%$, kemudian untuk respon total padatan terlarut whey dan rendemen hasil verifikasinya lebih rendah dari prediksi masing-masing sebesar $6,03^{\circ}$ Brix dan $14,01 \%$.

Hasil verifikasi kadar protein tidak berada pada rentang prediksi melainkan lebih tinggi, hal tersebut diduga dikarenakan kualitas susu sapi yang digunakan mempengaruhi kadar protein dangke. Susu sapi yang digunakan berasal dari KUD Batu, namun diduga susu tersebut mempunyai kualitas yang berbeda dengan yang digunakan sebelumnya karena diperoleh dari bebe-rapa peternak yang berbeda. Menurut Rybak (2014), terdapat keterkaitan antara kualitas susu dengan kualitas curd yang dihasilkan, hal ini merujuk peran penting protein susu yang berdampak pada jumlah kasein yang teragregasi dalam pem-bentukan curd sehingga mempengaruhi ka-dar protein curd yang diperoleh.

\section{Perbandingan Dangke Solusi Optimum dengan SNI : 01-2980-1992}

Dangke solusi optimum dibanding-kan dengan SNI nomor 01-2980-1992 ten-tang keju olahan karena dangke belum mempunyai SNI sehingga standar yang mendekati yaitu SNI keju olahan. Ber-dasarkan Tabel 5., kadar protein dan kadar abu sudah sesuai dengan SNI, sedangkan untuk kadar air dan kadar lemak belum sesuai dengan SNI. Tingginya kadar air dangke diduga pengaruh proses pene-kanan curd yaitu tekanan yang diberikan kurang maksimal karena hanya dilakukan secara manual. Menurut Carrol dan Phyllis (2012), penekanan curd yang baik dila-kukan secara mekanik dengan alat penekan sehingga pengeluaran whey menjadi efisien. Fox (2012) menambahkan, penekanan curd bertujuan mengurangi kelembaban, pene-kanan yang dilakukan ketika curd dalam keadaan panas akan dihasilkan curd dengan kadar air lebih rendah dengan tekstur curd padat. 
Tabel 5. Perbandingan SNI : 01-2980-1992, dengan dangke hasil solusi optimal

\begin{tabular}{lcc}
\hline \multicolumn{1}{c}{ Parameter } & $\begin{array}{c}\text { Dangke Solusi } \\
\text { Optimal }\end{array}$ & SNI : 01-2980-1992 \\
\hline Kadar Protein (\%) & 22,14 & Minimal 19,5 \\
Kadar Air (\%) & 50,17 & Maksimal 45 \\
Kadar Lemak (\%) & 18,33 & Minimal 25 \\
Kadar Abu (\%) & 2,25 & Maksimal 5,5 \\
\hline
\end{tabular}

Tabel 6. Rerata penilaian panelis terhadap organolpetik dangke

\begin{tabular}{lcccc}
\hline \multicolumn{1}{c}{ Organoleptik } & \multicolumn{2}{c}{ Dangke Solusi Optimal } & \multicolumn{2}{c}{ Dangke Komersial } \\
\cline { 2 - 5 } Dangke & Rerata & Keterangan & Rerata & Keterangan \\
\hline Warna & 4,36 & Netral & 5,08 & Agak Menyukai \\
Tekstur & 3,44 & Agak Tidak Menyukai & 5,24 & Agak Menyukai \\
Rasa & 2,32 & Tidak Menyukai & 4,48 & Netral \\
Aroma & 4,36 & Netral & 4,88 & Netral \\
\hline
\end{tabular}

Hasil kadar lemak dangke lebih rendah jika dibandingkan dengan kadar lemak SNI keju olahan, hal ini diduga dikarenakan kadar air dangke masih cukup tinggi sehingga mempengaruhi kadar lemak dangke. Martinez dan Jorge (2019) menyatakan, lemak dan air berperan dalam mengisi matriks kasein keju, kandungan air yang tinggi menyebabkan lemak pada keju rendah. Keju dengan lemak rendah memiliki sedikit globulaglobula lemak sehingga matriks keju didominasi ikatan antara kasein dan air (Gunasekaran, 2003).

\section{Organoleptik Dangke}

Warna Dangke

Rerata penilaian panelis terhadap warna dangke komersial yaitu agak menyukai dan dangke hasil solusi optimal yaitu netral (biasa). Pengamatan secara visual menunjukkan dangke komersial berwarna putih dan sedikit warna kekuningan pada permukaannya dan dangke hasil solusi optimal berwarna putih susu. Rerata penilaian warna dangke dilihat pada Tabel 6. Hatta et al. (2013) menyatakan, dangke yang dibuat menggunakan susu sapi segar menyebabkan warna dangke menjadi putih kekuningan, warna kekuningan tersebut karena sapi memilik karoten yang cukup tinggi sehingga dangke yang dihasilkan menjadi berwarna putih sedikit kekuningan. Menurut Saleh (2004), warna putih pada dangke disebabkan adanya dispersi cahaya oleh butiran-butiran mineral, protein serta lemak pada susu, dimana kasein susu membelokkan warna secara merata sehingga susu nampak berwarna putih.

\section{Tekstur Dangke}

Rerata penilaian panelis terhadap tekstur dangke komersial yaitu agak menyukai dan dangke hasil solusi optimal yaitu tidak menyukai. Tekstur dangke komersial lebih padat, kompak, dan kenyal sedangkan tekstur dangke hasil solusi optimal lebih lembut dan rapuh. Rerata penilaian tekstur dangke dilihat pada Tabel 6 .

Perbedaan tekstur dangke diduga karena pengaruh dari kadar air, dangke solusi optimal mempunyai kandungan kadar air lebih tinggi sehingga teksturnya menjadi tidak padat dan cenderung rapuh. Lee et al. (2009) menyatakan, kadar air tinggi dalam curd keju akan mempengaruhi tekstur dan umur simpan keju, diketahui kadar air mengurangi kekerasan curd keju serta menyebabkan rentan pada pembusukan. Abu dan Sri (2016) menambahkan, tingkat kekerasan pada tekstur keju dipengaruhi adanya kadar air dimana matriks keju mengikat air lebih tinggi sehingga tekstur keju menjadi lebih lembut, lunak serta kurang elastis.

\section{Rasa Dangke}

Rerata penilaian panelis terhadap tekstur dangke komersial yaitu netral dan dangke hasil solusi optimal yaitu tidak menyukai. Rerata penilaian rasa dangke dilihat pada Tabel 6. Dangke komersial memiliki rasa gurih khas susu dan tidak pahit sedangkan dangke hasil solusi opti-mal mempunyai rasa khas susu namun terasa pahit. Karatas et al. (2016) menyatakan, rasa pahit disebabkan oleh akumulasi peptida akibat adanya proteolisis atau aktivitas 
protease yang berlebihan karena penga-ruh enzim proteolitik yang diperoleh dari koagulan susu yang digunakan, selain itu rasa pahit pada keju diduga berasal dari asam lemak bebas karena proses lipolisis atau pemecahan lemak oleh enzim. Menurut Buckle et al. (2007), rasa pada dangke yang dihasilkan berkaitan dengan kandungan nutrisi didalamnya yaitu rasa manis dangke berasal dari lakstosa dan rasa asin dangke berasal dari garam mineral, dimana perpaduan rasa tersebut menimbulkan rasa gurih pada dangke yang diperoleh.

\section{Aroma Dangke}

Rerata penilaian panelis terhadap aroma dangke komersial yaitu netral namun cenderung menyukai dan dangke hasil solusi optimal yaitu netral. Rerata penilaian rasa dangke pada dangke dilihat pada Tabel 6 . Dangke komersial dan dangke hasil solusi optimal sama-sama mempunyai aroma susu yang khas, namun untuk dangke komersial mempunyai aroma susu yang lebih lemah dan dangke hasil solusi optimal mempunyai aroma susu yang lebih kuat. Menurut Friedrich dan Acree (2015), aroma ditimbulkan berasal dari proses pemanasan susu yang mempengaruhi kandungan senyawa volatil dari asam lemak susu dan mengubah struktur profil pada aroma susu. Aardt et al. (2001) menambahkan, curd keju memiliki beberapa senyawa volatil yang dapat menimbulkan aroma yaitu senyawa motional, senyawa 3-metilbutana dan senyawa 1oktentrion.

\section{SIMPULAN}

Konsentrasi enzim papain optimal sebesar $0,21 \%$ dan suhu pemanasan optimal sebesar $77,73{ }^{\circ} \mathrm{C}$ yang memiliki kadar protein dangke sebesar $11,93 \%$; total padatan terlarut whey dangke sebesar $6,31^{\circ}$ Brix; dan rendemen dangke sebesar $14,44 \%$. Tingkat kesukaan panelis terhadap dangke yaitu warna netral, tekstur agak tidak menyukai, rasa tidak menyukai dan aroma netral.

\section{DAFTAR PUSTAKA}

Aardt, -V. M., -J.S.E. Duncan, -E. Marcy, -T.E. Long, -C.R. Hackey. 2001. Effectiveness of polyethylene tereph-thalate and high density polyethy-lene in protection of milk flavour. Journal Dairy Science. 84(1), 1341-1347. https:// doi.org/10.3168 /jds.S0022-0302(01)70164-6

Abu, -B., Sri -U. 2016. Mutu keju putih rendah lemak diproduksi dengan bahan baku susu modifikasi. Buletin Peternakan. 40 (2), 144-156. https://doi.org/10.21059/ buletinpeternak.v40i2.9085

Arlene, -A., Anastasia -P. K., Adelia -P. 2014. The effects of milk types (cow, peanut, red bean) and enzyme types (rennet, papain, bromelain) towards the quantity and quality of cheddar cheese. International conference on engineering technology and industrial application. 101-436. ISSN 2407-4330. http://hdl.handle.net/11617/4979

Association Official Analitycal Chemistry [AOAC]. 2005. Official method of analysis. Horwitz William Publisher. Washington DC.

Awwaly, -K.U.A. 2007. Imobilisasi enzim renin mucor pusillus dengan matriks alginat dan aplikasinya dalam pembuatan keju. Journal of the Indonesian Tropical Animal Agriculture. 32(1), 222229. http:/ / eprints.undip.ac.id/262 55/1/32(4)2007p222-229.pdf

Baarri, -A.N., Anang -M.L., Septinika -K.A., Shigeru -H. 2018. Extending shelf life of indonesian soft milk cheese (dangke) by lactoperoxidase system and lysozyme. International Journal of Food Science. 1-7. https://doi.org/10.1155/2018/4305395

Bansal, -N., Patrick -F., Paul -L. 2007. Factors affecting the retention og rennet in cheese curd. Journal Agriculture Food Chemical. 55(1), 8219-9225. https://doi. org/10.1021/jf071105p

Buckle, -K.A., Edwards -R.A., Fleet -G.H., Wootton -M. 2007. Ilmu Pangan. Universitas Indonesia Press. Jakarta.

Carrol, -R., Phyllis -H. 2012. Making Cheese, Butter \& Yogurt. Storey Publishing. USA.

Chitranayak, -M., Menon -R.R., -F Magdaline -E., -K Jayaraj -R., -S Varalakshmi, -S Deshpande. Physico chemical characterization of paneer assessed by varying pressure-time combination. Indian Journal Dairy Science. 70(3), 1-7. https://www.researchgate.net/publicat ion/317286225_Physico_chemical_chara cterization_of_paneer_assessed_by_vary ing_pressure-time_combination 
Dattatreya, -A., Scott -A.R. 2006. Moderately acidic ph potentiates browning of sweet whey powder. International Dairy Journal. 16(2006), 822-823. https:// doi.org/10.10 16/j.idairyj.2005.07.006

Fox, -P.F. 2012. Cheese: chemistry, phsysics and microbiology. Springer. New York.

Gunasekaran, -S., Mehmet -M.A. 2003. Cheese Rheolgy and Texture. CRC Press. Florida.

Friedrich -J.E., Acree -T.E. 2015. Gas chromatography olfactometry ( $g c / 0)$ of diary product. State Agricultural Experiment Station. New York (US).

Hatta, -W., Mirnawati -B.S., Idwan -S., Ratmawati -M. 2013. Survei potensi dangke susu sapi sebagai alternatif dangke susu kerbau di Kabupaten Enrekang, Sulawesi Selatan. Jurnal Ilmu dan Teknologi Peternakan. 3(1), 40-50. https://www.researchgate.net/publicat ion/309427928_SURVEI_POTENSI_DA NGKE_SUSU_SAPI_SEBAGAI_ALTER NATIF_DANGKE_SUSU_KERBAU_DI_ KABUPATEN_ENREKANG_SULAWES I_SELATAN_Survey_on_the_Potency_of _Cow_Milk_Dangke_as_an_Alternative_ to_Buffalo_Milk_Dangke_in_Enreka

Hatta, -W., Mirnawati -B.S., Idwan S., Ratmawati M. 2014. Survei Karakteristik Pengolahan dan Kualitas Produk Dangke Susu Sapi di Kabupaten Enrekang, Sulawesi Selatan. Jurnal Ilmu dan Teknologi Peternakan. 3(3): 154-161. https://core.ac.uk/download/pdf/7762 2096.pdf

Karatas -S., Zeynep -H.T., Ebru -K. 2016. Reasons of Bitterness in Ultrafiltrated White Cheese. International Journal of Innovative Studies in Sciences and Engineering Technology. 2(9), 39-44. https://www.academia.edu/38460515/ REASONS_OF_BITTERNESS_IN_ULTR AFILTRATED_WHITE_CHEESE

Khattak, -F.M., -T.N. Pasha, -Z. Hayat, -A. Mahmud. 2006. Enzymes in poultry nutrition. Joernal AnimEPlant Science. 16(1): 1-2. https:/ / www.researchgate. net/publication/267838707_Enzymes_in _poultry_nutrition

Lawless, -H.T., Hildegarde -H. 2010. Senso-ry evaluation of food: Principles and practices. Springer. New York.

Lee, -M.R., Lee, -W.J. 2009. The role of ca equilibrium on the functional pro-perties of cheese: a review. Korean Journal of Food
Science Animal. 29(1), 545-549. https://doi.org/10.5851/kosfa.2009.29.5. 545

Martínez, -M., Jorge -F.V. 2019. Develop-ment and physicochemical characte-rization of a functional mozzarella cheese added with agavin. Journal Food Science Nutrition Research. 2(2), 87-107. http:/ / www.fortunejournals.com/articl es/development-and-physicochemicalcharacterization-of-a-functionalmozzarella-cheese-added-withagavin.html

Mukhlisah, -A.N., Arief -I.I., Taufik -E. 2017. Physical, microbial, and che-mical qualities of dangke produced by different temperatures and papain concentrations. Journal of Media Peternakan. 40(1): 63-70. https://doi.org/10 $.5398 /$ medpet.2017.40.1.63

Nguyen, -M., Norm -R., -S. Vigneswaran. 2003. By-product Recovery from Cottage cheese production by nanofil-tration. Journal of Cleaner Production. 11(2003), 803-807. https://doi.org/10.1016/S09596526(02)00130-0

Nollet, -L. Fidel -T. 2008. Handbook of processed meats and poultry analysis. CRC Press. Florida.

Nugroho -P., Bambang -D., Heni -R. 2018. Rendemen, nilai ph, tekstur, dan aktivitas antioksidan keju segar dengan bahan pengasam ekstrak bunga rosella ungu (Hibiscus sabdariffa L.). Jurnal Teknologi Pangan. 2(1), 33-39. https://doi.org/10.14710/jtp.2.1.\%25p

Pardede, -B.E., Adhitiyawarman, Savante -A. 2013. Pemanfaatan enzim papain dari getah buah pepaya (carica papaya l) dalam pembuatan keju cottage meng-gunakan bakteri lactobacillus bulgaricus. Jurnal Kimia Khatulistiwa. 2(3), 163-168.

http:/ jurnal.untan.ac.id/index.php/jk kmipa/article/view/3979

Rahman, -S. 2014. Studi Pengembangan Dangke sebagai Pangan Lokal Unggulan dari Susu di Kabupaten Enrekang. Jurnal Aplikasi Teknologi Pangan. 3 (1) : 41-45. http://journal.ift.or.id/files/3141 45\% 20Studi \% 20Pengembangan \%20Dang ke\%20sebagai\%20Pangan\%20Lokal\%20 Unggulan\%20dari\%20Susu\%20Di\%20Ka bupaten \%20Enrekang.pdf 
Rybak, O. 2014. The role of milk proteins in the structure formation of dairy products. Ukrainian Food Journal. 3(3): 350360. https:/ / www.cabdirect.org/cabdi rect/abstract/20153093367

Saini, -B.L. 2010. Introduction to biotechnology. University Science Press. New Delhi.

Saleh, -E. 2004. Dasar pengolahan susu dan hasil ikutan ternak. Universitas Sumatra Utara Press Sumatera Utara. Medan.

SNI 01-3546. 2004. TSS Gravimetri. Standar Nasional. Indonesia. Jakarta.

Suhandana, -M., Tati -N., -Laksmi A. 2013. Karakterisasi ekstrak kasar enzim polyphenol oxidase dari udang windu (Penaeus monodon). Jurnal Ilmu Dan Teknologi Kelautan Tropis. 5(2), 353-364. https://media.neliti.com/media/public ations/102879-ID-none.pdf

Sulmiyati, Rahmawati -M. 2017. Karakte-ristik fisik dan kimia air dadih (whey) dangke dengan level enzim papain yang berbeda. Jurnal Ilmu dan Teknologi Peternakan. 5(2), 102-106. https://www. researchgate.net/publication/326175502 _KARAKTERISTIK_FISIK_DAN_KIMIA _AIR_DADIH_WHEY_DANGKE_DEN GAN_LEVEL_ENZIM_PAPAIN_YANG _BERBEDA_Chemical_and_Physical_Pr operties_of_Dangke_Whey_Using_Diffe rent_Levels_of_Papain_Enzyme

Suyanti, Setyadjit, Abdullah -A. 2012. Produk diversifikasi olahan untuk meningkatkan niai tambah dan mendukung pengembangan buah pepaya di indonesia. Jurnal Litbang Buletin Teknologi Pascapanen Pertanian. 8(2), 63-70. http:// ejurnal.litbang.perta nian.go.id/index.php/bpasca/article/vi ew/5481

Walsh, -G. 2002. Proteins: Biochemistry and Biotechnology. John Wiley \& Sons. West Sussex United Kingdom.

Wardhani -D.H., Bakti -J., Abdullah, Suherman, Heri -C. 2018. Komparasi jenis koagulan dan konsentrasinya terhadap karakteristik curd pada pembuatan keju lunak tanpa pemeraman. Jurnal Rekayasa Kimia dan Lingkungan. 13(2), 209 - 216. https:/ / 10.23955/rkl. v13i2.12157

Warisno. 2003. Budi Daya Pepaya. Kasinius. Yogyakarta.

Waziiroh, -E., Nur -I. 2016. Biskuit berbasis pure ubi jalar oranye (Ipomea batatas L.) bagi penderita autis. Jurnal Teknologi Pertanian. 17(2), 79-90. https:/ / www. e-jurnal.com/2017/12/biskuit-berbasispure-ubi-jalar-oranye.html

Winarti, -S., Jariyah, Yudi -P. 2007 Proses pembuatan VCO (Virgine Coconute Oil) secara menggunakan papain kasar. Jurnal Teknologi Pertanian. 8(2),135-141. https:/ / www.academia.edu/28585159/ PROSES_PEMBUATAN_VCO_Virgine_ Coconut_Oil_SECARA_ENZIMATIS_M ENGGUNAKAN_PAPAIN_KASAR

Yuniwati, -M. Yusran, Rahmadany. 2008. Pemanfaatan enzim papain sebagai penggumpal dalam pembuatan. Seminar Nasional Aplikasi Sains dan Teknologi. IST AKPRIND. Yogyakarta. http://reposito ry.akprind.ac.id/repo/conferencepaper/pemanfaatan-enzim-papainsebagai-penggumpal-dalam-pembuatan 